\title{
The Environmental Significance of Bioindicators in Sewage Treatment
}

\section{Judit NÉMETH-KATONA ${ }^{*}$ (HU) katona.judit@rkk.uni-obuda.hu}

\section{BIOGRAPHICAL NOTES}

MDr. Judit Németh-Katona PhD. is an associate professor at the Óbuda University, Institute of Environmental Protection, Rejtő Sándor Faculty of Light Industry and Environmental Protection Engineering, Budapest. She is a Doctor of Philosophy in the scientific field: Environmental Sciences (the University of West Hungary), as well as she is a geographer, biologist and ecologist (the Eötvös Loránd University, Budapest). Her professional specialisation is the environmental protection engineering.

\section{KEY WORDS}

Environmental Quality, Sewage Treatment, Polysaprobic Sewage Water, Mezosaprobic Sewage Water

\section{ABSTRACT}

The presentation is about the significance of the bioindicators concerning environmental protection within the process of cleaning sewage. The existence of one or multi-celled organisms indicates the presence, condition or absence of certain parts of the water cleaning process. This way the optimal operation of the purifying appliances can be checked continuously and controlled in an environment friendly way.

\section{INTRODUCTION}

Life is dependent on water: an indispensable compound for all living organisms. It provides the medium, the dissolvent substance, and reaction agent for intracellular biochemical processes. It is one of the vital temperature controllers of the biosphere. The total water supply of the Earth is approximately 1340 million cubic km but less than $3 \%$ of that $(36,8$ million cubic $\mathrm{km})$ is fresh water, and the ratio of surface waters, lakes, streams, rivers, and groundwater is even less, only $64 \%$, or 8,3 million cubic $\mathrm{km}$. The population of the Earth is presently 6.1 billion (US), (or 6,1 milliard GB). Based on current tendencies, this number is growing by 70-90 million per year. One of the most pressing global environmental challenges, due to the intensive population growth, is the lack of sufficient fresh water. Overpopulation, however, is not merely a consumption issue (5500 cubic km annually). The amount of wastewater or sewage water produced by the population is also increasing in direct proportion to population growth. Consequently, the pollution of water supplies, previously assumed to be of infinite capacity, has been significantly increased in the last three decades, thus sewage treatment has become a most pressing and immediate issue presently.

There are two options for the final disposal of sewage water. It can either be entered in natural waters, or in the ground, thus returning to the natural cycle. The self-purification capacities of the natural waters and the ground, however, are no longer able to handle the constantly increasing amounts of organic matter, and they have absolutely 
no resistance to toxins.

Following the example of self-purification in natural waters, biotechnological procedures have been used in sewage treatment more and more extensively, both in water clarification procedures, and in the related issue of water quality qualification.

\section{ENVIRONMENTAL QUALITY}

Basically, there are two approaches to examine and determine water quality, and in a broader sense, environmental quality.

One approach makes the qualifications based on the indicators of end use (e.g. the parameters of drinking, industrial, irrigation, and sewage water), and interprets the data according to the appropriate standards. This approach is not quite operative because of its oversimplification. Obviously, any entity in the environment has a "quality" not only if it is used for some purpose. This is to confuse quality with the concepts of practicability, adequacy or utility.

The other approach determines environmental quality as the totality of attributes. This means that environmental quality is not determined based on a single characteristic, and it does not single out one variable, e.g. the temperature, the light conditions, the phosphorus content, etc.

Water as an environmental element can be defined as the sum of hydrological, physical, chemical, and biological characteristics. Some factors to be considered are: the properties of currents, the temperature and translucency of water, its free oxygen content, its ionic composition, its richness in different organic matter and living organisms, and various other factors.

If one wants to determine the actual quality of an environmental element, one cannot be limited to the examination of the relevant properties of the components separately. The qualitative "junctions" of any material system are not only, and moreover not primarily, characterized by the number of and the values of the components, but rather by their specific structure, i.e. the particular system of interconnections of the components within the domains of the given system. To analyze and interpret the complexity of the specific particularities created by the interactions of the individual constituents is significantly more complicated and more intricate than to study the idiosyncrasies of the individual components.
The accumulation of organic matter in natural waters, i.e. a positive change in the trophic state, is called eutrophication. The trophic state is defined by the organic matter content of a particular body of water. This state is induced by specific attributes as variables, e.g. the available amounts of phosphorus and/or nitrogen, the chlorophyll content, the algae biomass. It would be erroneous to reduce the cause of eutrophication to a single attribute or property. The interactions of various factors are required to produce the state of increased organic matter content, such as an energy source, several micro and macro elements, living organisms.

In the waters of Hungary, the trophic state is limited and determined primarily by the phosphorus content, sometimes by nitrogen, but it can also be the level of light available. Consequently, the subsequent phases of sewage treatment (i.e. the aerobic, the anoxic, and the anaerobic) must accomplish the decomposition of organic matter the transformation of ammonia, nitrite, and nitrate, and must remove the excess amounts of phosphorus in order to produce water that is suitable to be absorbed by natural waters without triggering eutrophication, and can be returned to the natural cycle.

\section{BIOINDICATORS}

The purity level of water, the current relevant properties of water quality can be determined in a fast, efficient, and cost effective way using bioindicators.

\section{INDICATION OF POLYSAPROBIC PROCESSES AND OXYDEN DEFICIENCY}

An increased number of several different bacteria, the presence of Cyanophyta, Zooflagellata, and Ciliata, is an indication of water overloaded with organic matter, i.e. an indication of polysaprobic processes and oxygen deficiency. Our observations can determine if the nutrient content of the sewage water was insufficient, or toxic substances entered the system. Water like that has a high concentration of organic matter, the nutrient to microorganism load ratio is between 0.4 and 1.5 The load per volume is excessive, thus aeration is inefficient with very little oxygen present. The sludge forming time is between 0.5 and 2 days, resulting in poor sewage treatment efficiency. As a consequence of the overload, only small clusters 
of sludge are forming, and they are settling slowly, with lots of bacteria floating freely in the water (10 entities per $\mathrm{ml}$ ).

Microorganism indicators are considered excellent water qualifiers because although they all call attention to a system overload, they indicate the cause and gravity of the situation in their own specific way.

The presence of nematode bacterium Thiotrix nivea (See Fig. 1) is an indication of the final stage, the ultimate putrefaction of water: hydrogen sulphide indicator. In this case it is necessary to empty and clean the aeration tank. This stage can be avoided if the other indicators are paid attention to in a timely manner.

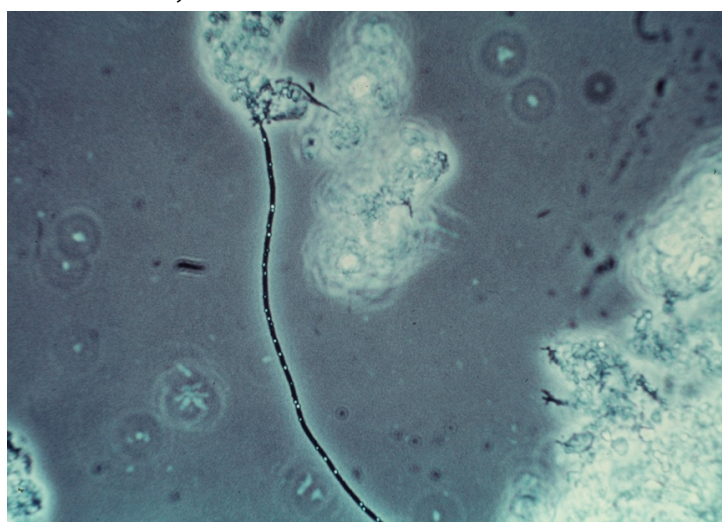

Fig. 1 Thiotrix nivea (magnified 400 times)

The presence of Spirillum and Spirochaeta species (See Fig. 2) signals the first stage of oxygen deficiency and an increase in the load. The Sarcina and Streptococcus phyla indicate a shift toward overload, alert of anaerobic processes, and the creation of stagnant "dead zones."

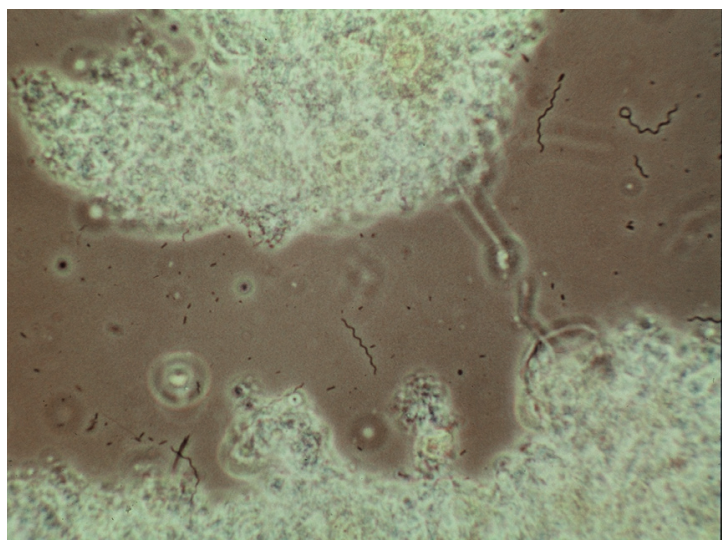

Fig. 2 Spirochaeta (magnified 250 times)
Sulphur bacteria, Thiocystis, Chromatium, and Beggiatoa species (See Fig. 3) point to insufficient clarification level, the formation of hydrogen sulphide, and the stage of putrefaction due to oxygen deficiency. A significant increase in the number of these bacteria results in a white, "furlike" coating.

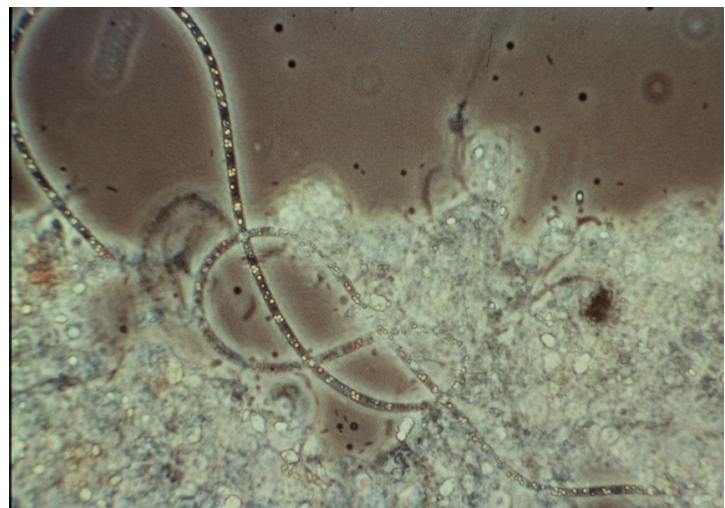

Fig. 3 Beggiatoa thread (magnified 400 times)

The swelling and movement of the sludge, usually caused by the decomposition of nitrogen compounds, are indicated by the presence of Nocardia, Zooglea (See Fig. 4).

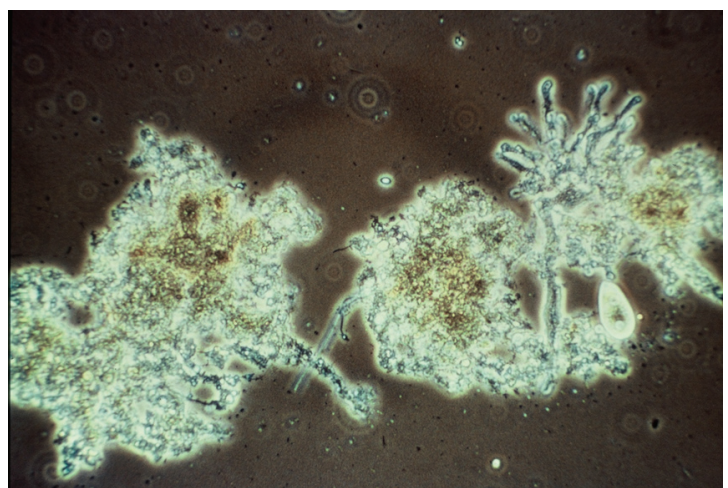

Fig. 4 Zooglea (magnified 400 times)

The flagellate protozoa (See Fig. 5) indicator organisms (Oikomonas, Trigonomonas, Trepomonas, and Bodo species, found in heavily loaded water rich in organic matter, show characteristics of both fauna and flora.

Besides bacteria and flagellate protozoa, the most significant indicator organisms are ciliate protozoa. The presence of these organisms indicates oxygen deficiency, system overload, and putrefaction. Ciliates most common in polysaprobic water are the Paramecium and Vorticella species (See Fig. 6). 


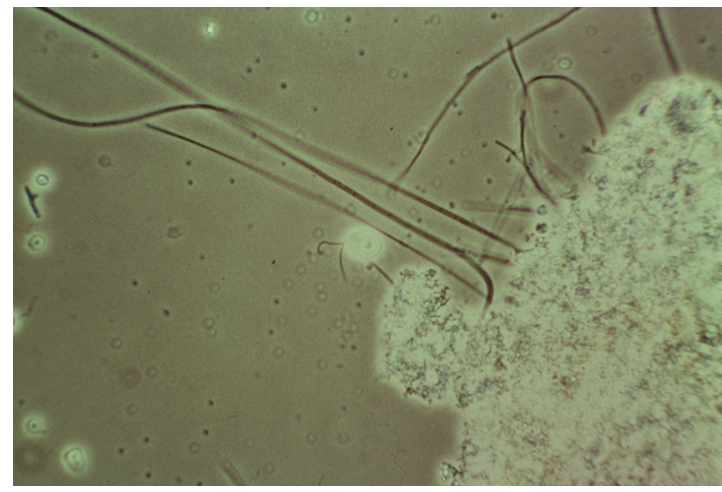

Fig. 5 Zooflagellata (magnified 250 times)

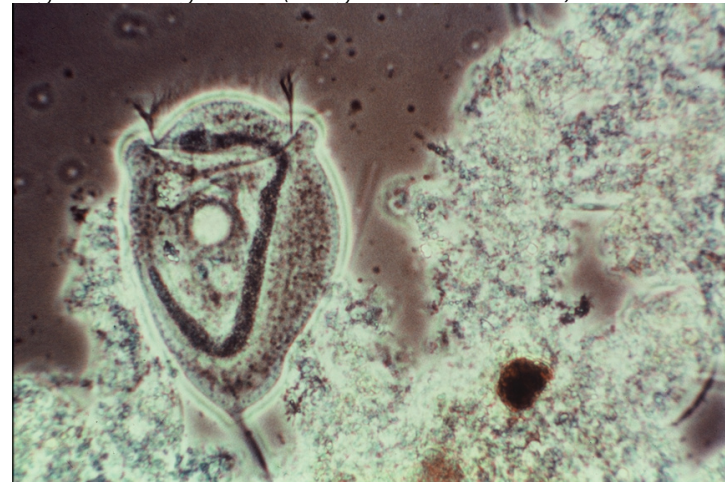

Fig. 6 Vorticella (magnified 400 times)

\section{INDICATION OF MESOSAPROBIC SEWAGE WATER}

In mezosaprobic sewage water the organic matter load is medium, the nutrient to microorganism ratio is $50 \%$ less than in polysaprobic water where the organic matter content is high. Sewage sludge is formed in 3,5 to 7 days, big clusters are formed that settle easily, and the freely floating bacteria are few. The free oxygen content is 4 to $6 \mathrm{mg}$ per liter, which means sufficient aeration. Optimal conditions are indicated by the presence of certain ciliate protozoan: Chilodonella (See Fig. 7), Litonotus, and Aspidisca species. They signal the process of nitrification, decreased ammonia level, and favorable aerobic (i.e. pertaining to the amount of oxygen) conditions).

\section{INDICATION OF OLIGOSAPROBIC WATER}

Oligosaprobic water is poor in nutrition, and the decomposition of organic matter is at a low level. It may be characterized by excessive aeration, and the clusters floating in the water are small and loosely structured. This condition is indicated primarily by the thread bacterium Microthrix parvice-
Ila. This bacterium occurs frequently in the winter months, and can become a dominating organism. Epistilis ciliate protozoa (See Fig. 8) are present in large numbers when the efficiency of sewage treatment is above $65 \%$.

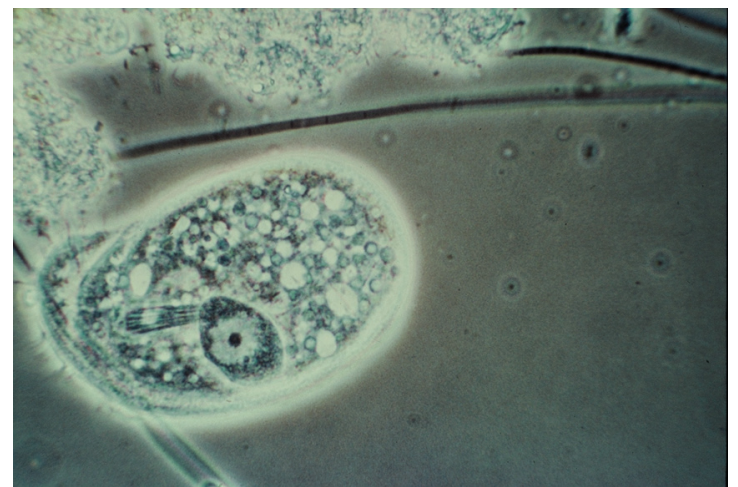

Fig. 7 Chilodonella (magnified 400 times)

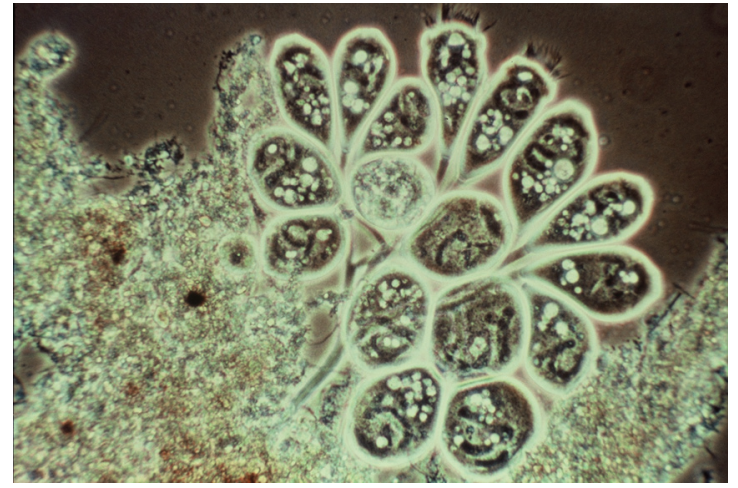

Fig. 8 Epistilis sp. (magnified 100 times)

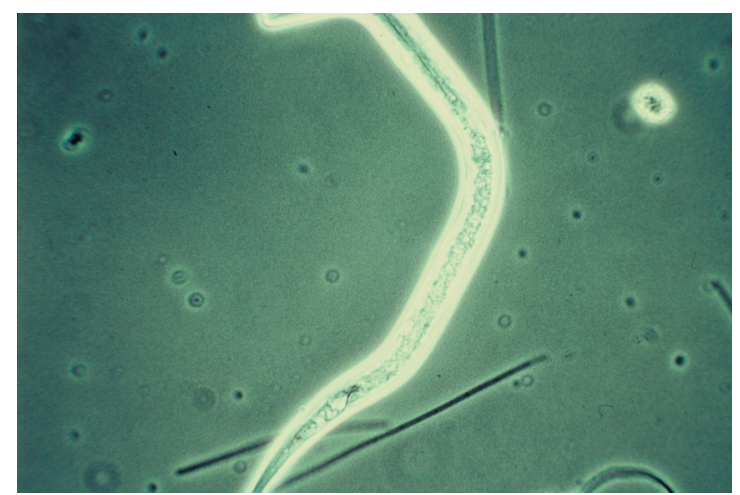

Fig. 9 Nematoda sp. (magnified 250 times)

Stabilized (aged) sewage sludge is indicated by the presence of metazoan organisms since they need more time to reproduce than the protozoic protocysts and bacteria. The most characteristic indicators are Tubifex tubifex of the nematodes (See Fig. 
9), and the rotifer group (Rotatoria) (See Fig. 10). Due to their filtering feeding method they reduce the number of bacteria outside the clusters, they loosen the structure of the clusters thus the bacteria inside the clusters have access to more oxygen.

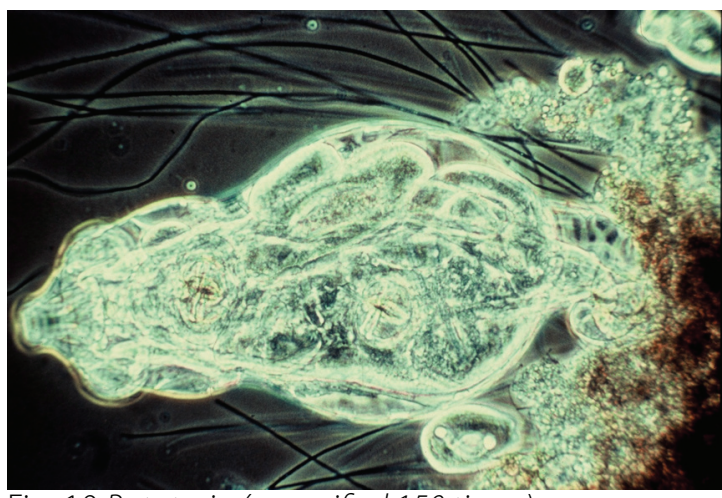

Fig. 10 Rotatoria (magnified 150 times)

\section{CONCLUSIONS}

Bioindicators indicate the presence and condition of the different stages of sewage treatment, also indicating the absence or excessive level of an entity. Observing the bioindicators, the quality of water, and the condition and operations of the treatment equipment can be continuously checked and controlled in a cost effective way. Thus the study of bioindicators is absolutely justifiable.

\section{REFERENCES}

[1] Anger, I. - Ködöböcz, L. - Bíró, B.: 2004. Mikrobacsoportok herbicid-szennyvíz kombinációkkal szembeni érzékenységének vizsgálata modellkísérletekben Agrokémia és Talajtan Vol.53. No.3-4 pp 331-342

[2] Kárpáti, Á.: 2002. Sewage sludge under the Microscope Aerobic sewage Treatment Methods: Using sewage sludge and other Methods Veszprém, Hungary pp. 3-55

[3] Nemethne-Katona J.: 2003. The Biological Fundamentals of Environmental sciences Budapest, Hungary pp. 5-260

[4] Pesti M.: 2001. Comprehensive Microbiology Dialo Kampus, Hungary pp. 3-89

[5] Veliskova, I.: 2006. Problem of water pollution and ways of solution Cereal Research Communications, pp. 101-103

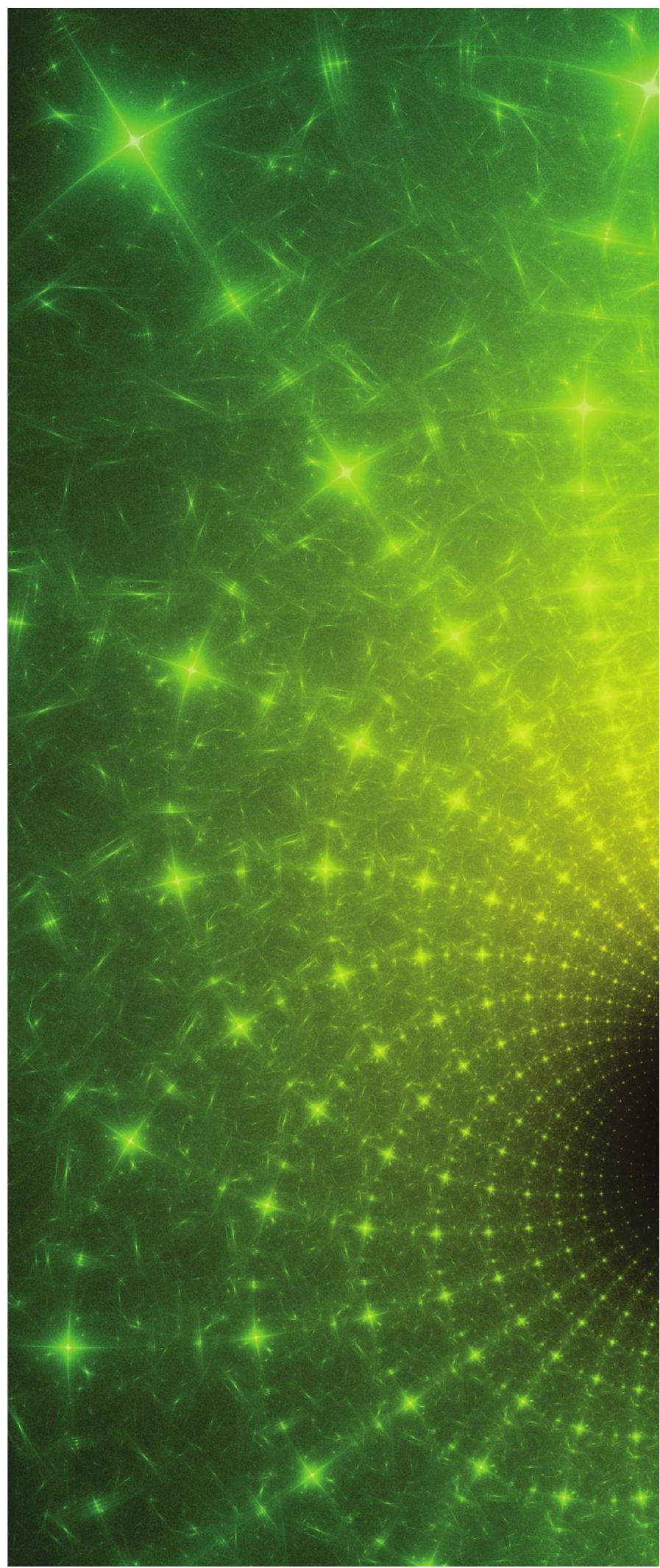




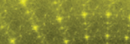<smiles>[CH]1[CH]CC1</smiles><smiles>[GeH3]</smiles> 